\begin{tabular}{|l|l|l||}
\hline \multicolumn{2}{|c|}{ PublisherInfo } \\
\hline \hline PublisherName & $:$ & BioMed Central \\
\hline \hline PublisherLocation & $:$ & London \\
\hline \hline PublisherImprintName & $:$ & BioMed Central \\
\hline \hline
\end{tabular}

\title{
Mitochondrial mutation associated with hearing loss
}

\begin{tabular}{|l|l|l||}
\hline \multicolumn{2}{|c|}{ ArticleInfo } \\
\hline \hline ArticleID & $:$ & 3985 \\
\hline \hline ArticleDOI & $:$ & $10.1186 /$ gb-spotlight-20010221-01 \\
\hline \hline ArticleCitationID & $:$ & spotlight-20010221-01 \\
\hline \hline ArticleSequenceNumber & $:$ & 56 \\
\hline \hline ArticleCategory & $:$ & Research news \\
\hline ArticleFirstPage & $:$ & 1 \\
\hline \hline ArticleLastPage & $:$ & 2 \\
\hline \hline & $:$ & RegistrationDate : 2001-02-21 \\
ArticleHistory & $:$ & OnlineDate \\
\hline \hline ArticleCopyright & $:$ & BioMed Central Ltd2001-02-21 \\
\hline \hline ArticleGrants & $:$ & \\
\hline \hline ArticleContext & $:$ & 130592211 \\
\hline \hline
\end{tabular}




\section{Jonathan B Weitzman}

Email: jonathanweitzman@hotmail.com

The identification of alleles associated with complex hearing defects, such as presbyacusis (agerelated hearing loss, AHL), presents a formidable challenge to geneticists. In the February Nature Genetics Johnson et al. describe their use of elegant mouse breeding experiments to identify the first example of a mitochondrial DNA (mtDNA) mutation that acts as a modifier of a nuclear AHL locus (Nat Genet 2001, 27:191-194). They performed a series of reciprocal backcrosses between three hearing-impaired inbred strains and a wild-type strain. Johnson et al. identified an mtDNA locus in one of these strains, the $\mathrm{A} / \mathrm{J}$ strain, which affects hearing loss when mice are homozygous for the nuclear Ahllocus on mouse chromosome 10. Analysis of the A/J mtDNA genome revealed a single adenine nucleotide insertion in the $t R N A-A r g$ gene. This unique example of nuclear-mitochondrial interaction will shed light on our understanding of human hearing impairmentconditions.

\section{References}

1. Nature Genetics, [http://genetics.nature.com]

2. Assessment of hearing in 80 inbred strains of mice by ABR threshold analyses.

3. A major gene affecting age-related hearing loss is common to at least ten inbred strains of mice.

4. Mus musculus mitochondrion, complete genome, [http://www.ncbi.nlm.nih.gov/cgi-bin/Entrez/ framik?db=Genome\&gi=10418]

5. Mitochondrial deafness mutations reviewed.

This PDF file was created after publication. 